\title{
On the way to COVID-19 vaccine development: tireless efforts and outcomes
}

\author{
Tapas Pramanik ${ }^{1}$, Tapas Kumar Sur ${ }^{2}$
}

\section{Author(s) info:}

${ }^{1}$ Professor \& Head, Department of Physiology, Nepal Medical College, Kathmandu, Nepal

${ }^{2}$ Research Scientist, Multidisciplinary Research Unit (ICMR), R.G. Kar Medical College, Kolkata, India

\section{Correspondence:}

\section{Dr. Tapas Pramanik, PhD}

Department of Physiology, Nepal Medical College, Kathmandu, Nepal

Email:

drpramanik@hotmail.com

DOI :

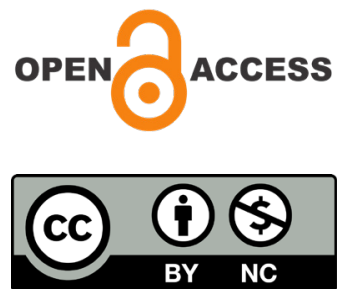

C JPSN

\section{SUMMARY}

Novel corona virus disease (COVID-19), since its emergence in November 2019, took the toll of a huge number of human lives. It is a $\beta$-corona-virus also known as SARS-CoV2. The safest and most effective way to prevent the disease is definitely vaccination amongst the large population. To the best of our knowledge, more than 200 vaccine candidates for COVID-19 were developed by the scientists of research institutions and pharmaceutical companies and nearly 52 candidates were in human trials. Till now, only 15 vaccines are being offered to the general population in the world, out of which 2 vaccines are RNA, 6 are conventional inactivated, 5 viral vector and 2 protein subunit. Here, we tried to unfold the events and efforts behind the successes of new innovations of COVID-19 vaccines, the world has achieved yet.

\section{INTRODUCTION}

Novel corona virus disease (COVID-19) has affected the normal life of mankind all over the world. Since its emergence in November 2019, it has spread to 188 countries and 25 territories around the globe.[1] It took the toll of a huge number of human lives even in developed countries. WHO declared it as a Public Health Emergency of International Concern.[2] It is a $\beta$-corona-virus also known as SARS-CoV2. The full genome of SARSCoV2 was sequenced in January, 2020.[3] The incubation period of the virus ranges from 2-14 days with a median of 5.1 days. The symptoms include fever, dry cough, fatigue, shortness of breath, chills, muscles pain, headache, gastric disturbances and weight loss.[4] World Health Organization (WHO) suggested people to increase immunity by adapting balanced diet, regular exercise and to avoid watching television news regularly and repeatedly to get rid of the panic that affects mental health badly. Physical distancing, maintenance of personal hygiene, wearing masks, sanitizing hands and disinfecting of the surfaces are considered as major steps to protect individuals from infection.[5] Nevertheless, to 
prevent the spread of this pandemic, vaccination might be the most effective therapy to generate herd immunity in the population.[6] Last one year, scientists all around the world are taking the challenge to discover harmless and effective vaccines to save the humanity from the deadly virus. The urgency to develop COVID-19 vaccine led to compressed schedules that shortened the standard vaccine development time-line without hampering the progress through several phases of clinical trials to test for safety, immunogenicity, effectiveness, dose levels and adverse effects of the candidate vaccine.[7] The Coalition for Epidemic Preparedness Innovations (CEPI) is rendering efforts to finance and coordinate research on a vaccine for COVID-19. Besides CEPI's funded initiatives, researchers are also working to develop relevant candidates and solutions, to find out successful vaccines. Within December 2020, more than 200 vaccine candidates for COVID-19 were developed by the scientists of research institutions and pharmaceutical companies and nearly 52 candidates were in human trials. Recently, 15 vaccines are being offered to the general population in the world, out of which 2 vaccines are RNA, 6 are conventional inactivated, 5 viral vector and 2 protein subunit.[8] Till date, whatever the scientists accomplished and developed vaccines against Covid-19, may not be of full proof and unquestionable, but these tireless efforts may save millions of lives throughout the world. In this juncture, we have tried to unfold the events and efforts behind the successes of new innovations of COVID-19 vaccines.

\section{CHOICE OF COVID-19 ANTIGEN}

SARS-CoV-2 virus contains four structural proteins namely, spike (S), nucleocapsid $(\mathrm{N})$, envelope (E), and membrane $(\mathrm{M})$ proteins which are encoded by the 3 '-end of the viral genome. It has a large $(30+\mathrm{kb})$ single stranded positive sense ss-RNA genome encased by a helical neucleocaspid. Genome has an outer envelope comprised of matrix protein, envelope protein and spike protein (S).[9] S-protein contain receptor binding domain that binds human angiotensin converting enzyme-2 (hACE2) and penetrate into the cell. Among all 4 structural proteins, S-glycoprotein, being large multifunctional trans-membrane protein, plays the vital role in viral attachment, fusion and penetration into the host cell. S-1 subunit of S-protein has $\mathrm{N}$ terminal domain and receptor binding domain
(RBD).[10] The primary endeavour of the scientists is to produce S-protein neutralizing antibodies in the vaccinated humans and they focussed $S$ protein as target antigen for vaccine development.[11,12]

\section{TYPES OF COVID-19 VACCINE}

There are three main approaches to designing any vaccine viz. (i) whole virus or bacterium, (ii) the parts of the virus that triggers the immune system, or (iii) just the genetic material of the virus. Conventionally vaccines prepared and administered in humans are either live attenuated viruses, or inactivated viruses, or protein or proteinpolysaccharide conjugated subunit or virus-like particles.[13] In recent years bioengineering technological knowledge are applied to manufacture vaccines from composed of nucleic acids (DNA or RNA), viral vectors or recombinant proteins.[14] All such procedures are applied to develop vaccine against SARS-CoV2. At present, 442 interventional studies have been registered for Covid-19 vaccine in the Clinical Trial of NIH, US National Library of Medicine.[15]

\section{Protein sub-unit vaccines}

Many efforts have been directed towards the development of the vaccines against COVID-19, to avert the pandemic and most of the developing vaccine candidates have been using the S-protein of SARSCoV-2.[16] Novavax (NVX-CoV2373) is a nano-particle based immunogenic vaccine, based upon the recombinant expression of the stable pre-fusion, coronavirus S-Protein. In the animal models, a single immunization resulted in the high level of anti-spike protein antibodies which blocked the hACE2 receptor binding domain and could elicit SARS-CoV-2 wild type virus-neutralizing antibodies.[17]

\section{Viral vectored vaccines}

Vaccine based on viral vectors offers a long term and high level of antigenic protein expression. These vaccines trigger and prime the cytotoxic T-cells and ultimately lead to the elimination of the virus infected cells.[18] These vaccines are highly specific in delivering the genes to the target cells, highly efficient in the gene transduction, and efficiently induce the immune response. Covishield or Vaxzevria (ChAdOx1 nCoV-19) was developed 


\section{Table 1: Development of Covid-19 vaccines}

\begin{tabular}{|c|c|c|c|c|c|}
\hline Vaccine & $\begin{array}{l}\text { Brand } \\
\text { name }\end{array}$ & $\begin{array}{l}\text { Vaccine } \\
\text { type }\end{array}$ & $\begin{array}{l}\text { Developed \& } \\
\text { manufactured } \\
\text { by }\end{array}$ & $\begin{array}{l}\text { Trial } \\
\text { location }\end{array}$ & Authorized for use in \\
\hline $\begin{array}{l}\text { Pfizer- } \\
\text { BioNTech }\end{array}$ & Comirnaty & m-RNA & $\begin{array}{l}\text { BioNTech } \\
\text { (Germany) \& } \\
\text { Pfizer (USA) }\end{array}$ & Multinational & $\begin{array}{l}84 \text { countries including } \\
\text { USA, EU, UK, Japan etc. }\end{array}$ \\
\hline $\begin{array}{l}\text { Oxford- } \\
\text { AstraZeneca }\end{array}$ & $\begin{array}{l}\text { Covishield \& } \\
\text { Vaxzevria }\end{array}$ & Viral vector & $\begin{array}{l}\text { Oxford University } \\
\text { \& AstraZeneca \& } \\
\text { Serum Institute of } \\
\text { India }\end{array}$ & Multinational & $\begin{array}{l}\text { UK, USA, EU, Japan, } \\
\text { Canada, Bangladesh, } \\
\text { Australia etc. }\end{array}$ \\
\hline $\begin{array}{l}\text { Johnson \& } \\
\text { Johnson }\end{array}$ & $\begin{array}{l}\text { Janssen } \\
\text { COVID-19 }\end{array}$ & Viral vector & $\begin{array}{l}\text { Johnson \& } \\
\text { Johnson } \\
\text { (Netherlands \& } \\
\text { USA) }\end{array}$ & Multinational & USA, Brazil, South Africa \\
\hline Moderna & $\begin{array}{l}\text { Moderna } \\
\text { COVID-19 }\end{array}$ & m-RNA & Moderna (USA) & USA & $\begin{array}{l}45 \text { countries including } \\
\text { USA, Canada, EU, UK, } \\
\text { Singapore etc. }\end{array}$ \\
\hline Sputnik V & $\begin{array}{l}\text { Sputnik V \& } \\
\text { Gam-COVID- } \\
\text { Vac }\end{array}$ & Viral vector & $\begin{array}{l}\text { Gamaleya } \\
\text { Research Institute } \\
\text { of Epidemiology } \\
\text { and Microbiology } \\
\text { (Russia) }\end{array}$ & Russia & $\begin{array}{l}45 \text { countries including } \\
\text { India, Brazil, China, South } \\
\text { Korea, Hungary etc. }\end{array}$ \\
\hline Covaxin & Covaxin & $\begin{array}{l}\text { Inactivated } \\
\text { virus }\end{array}$ & $\begin{array}{l}\text { Bharat Biotech \& } \\
\text { ICMR (India) }\end{array}$ & India & $\begin{array}{l}\text { India, Nepal, Iran, } \\
\text { Zimbabwe, Mauritius, } \\
\text { Mexico, Philippines etc. }\end{array}$ \\
\hline BBIBP-CorV & $\begin{array}{l}\text { Sinopharm } \\
\text { COVID-19 }\end{array}$ & $\begin{array}{l}\text { Inactivated } \\
\text { virus }\end{array}$ & $\begin{array}{l}\text { Sinopharm } \\
\text { (China) }\end{array}$ & $\begin{array}{l}\text { Multinational } \\
\text { (Argentina, } \\
\text { UAE, Pakistan, } \\
\text { Peru etc.) }\end{array}$ & $\begin{array}{l}\text { China, Nepal, UAE, } \\
\text { Pakistan, Mexico etc. }\end{array}$ \\
\hline CoronaVac & CoronaVac & $\begin{array}{l}\text { Inactivated } \\
\text { virus }\end{array}$ & $\begin{array}{l}\text { Sinovac Biotech } \\
\text { (China) }\end{array}$ & $\begin{array}{l}\text { Brazil, Chile, } \\
\text { Indonesia, } \\
\text { Philippines }\end{array}$ & Brazil, Turkey \\
\hline Novavax & $\begin{array}{l}\text { Covovax \& } \\
\text { NVX-CoV2373 }\end{array}$ & $\begin{array}{l}\text { Recombinant } \\
\text { nanoparticle } \\
\text { vaccine }\end{array}$ & Novavax (USA) & $\begin{array}{l}\text { UK, South } \\
\text { Africa }\end{array}$ & UK, Canada \\
\hline
\end{tabular}

at Oxford University and consists of a replicationdeficient chimpanzee adenoviral vector containing the SARS-CoV-2 structural surface glycoprotein antigen gene. The previous animal studies have suggested that a single shot should induce the immune response.[19] An interim analysis of ongoing four randomized clinical trials in Brazil, South Africa and UK suggested that ChAdOx1 nCoV-19 has an acceptable safety profile and has been found to be efficacious against symptomatic COVID-19.[20]

\section{3. mRNA vaccines}

mRNA is a promising, non-infectious and a nonintegrating platform with almost no potential risk of mutagenesis. The immunogenicity of the mRNA can be minimized and modifications can be made to increase the stability of these vaccines. Moreover, the anti-vector immunity is also avoided as the mRNA is the minimally immunogenic genetic vector, allowing repeated administration of the vaccine.[21] Moderna (mRNA-1273) vaccine is composed of synthetic mRNA encapsulated in Lipid 
Nano Particle which codes for the full-length, prefusion stabilized S-protein of SARS-CoV-2. It can elicit a highly S-protein specific antiviral response. The geometric mean of RBD specific antibody titers showed a rapid increase in all the participants. Sero-conversion was observed after 15 days and the median magnitude of antibody responses was similar to the magnitude in convalescent sera. It is relatively safe as it does not contain the inactivated pathogen or the sub-units of the live pathogen and found to be well tolerated in the $25 \mu \mathrm{g}$ and 100 $\mu \mathrm{g}$ dose cohorts.[22] Another m-RNA vaccine is Comirnaty (BNT162b1), developed by PfizerBioNTech. It is a codon-optimized mRNA vaccine that encodes for the trimerized SARS-CoV-2 RBD, a critical target of the virus $n A b$. The vaccine showed an increased immunogenicity due to the addition of T4 fibritin-derived fold on trimerization domain to the RBD antigen.[23]

\section{DNA vaccines}

DNA vaccineencodes for the antigen and an adjuvant which induces the adaptive immune response. The transfected cells express the transgene which provides a steady supply of the transgene specific proteins which is quite similar to the live virus. Furthermore, the antigenic material is endocytosed by the immature Dendritic Cells which ultimately present the antigen to the CD4+ and CD8+ T cells in association with MHC II and MHC I antigens on the cell surface hence stimulating effective humoral as well as cell-mediated immune responses.[24] Inovio Pharmaceuticals has developed the DNA plasmid vaccine INO-4800 from Lassa virus, Nipahvirus, HPV, HIV and Filovirus. The presence of functional antibodies and $\mathrm{T}$ cell response in the preclinical trials suggest that the vaccine can produce an effective immune response within 7 days post-vaccination.[25] Zydus Cadila has developed ZyCoV-D vaccine, a genetically engineered DNA plasmid based vaccine encoding for the membrane proteins of the virus.[26]

\subsection{Live Attenuated Vaccines (LAV)}

Live vaccines are derived from wild viruses or bacteria. These wild viruses or bacteria are attenuated, or weakened, in a laboratory, usually by repeated culturing. Covaxin (BBV152) was developed by Bharat Biotech and Indian Council of Medical Research (ICMR). It is the whole virion inactivated vaccine. It contains $6 \mu \mathrm{g}$ of whole-virion inactivated SARSCoV-2 antigen (NIV-2020-770).

\section{VACCINATIONS}

After completion of phase III trials, 15 vaccines have exhibited significant efficacy (95\%) in preventing symptomatic Covid-19 infections and authorized by national regulatory authority for public use. UK was the first country in the world to approve Pfizer-BioNTech's Covid-19 vaccine on December, 2020. According to recent data, $704,983,864$ individuals have received at least one dose of a Covid-19 vaccine throughout the world, which is only $9.0 \%$ of world population. [27] Even if sustained immunity is attained after infection by Covid-19, estimates are that $60-70 \%$ of a population would need to be immune to achieve herd immunity against SARS-CoV2. US-FDA approved only three Covid-19 vaccines for USA, namely Pfizer-BioNTech, Moderna and Johnson \& Johnson. Most of the countries have given the priorities of vaccination to their elderly persons, healthcare workers, state employed workers, police and susceptible population.

\section{DISCUSSION AND CONCLUSION}

The safest and most effective way to prevent the disease is definitely vaccination amongst the large population. In spite of the tireless efforts a definite goal has not been reached yet. According to WHO, vaccine must provide a highly favourable benefit-risk contour, with high efficacy, only mid or transient adverse effects and no serious ailments. [28] Vaccine must be suitable for all ages, pregnant and lactating women and should provide a rapid onset of protection with a single dose and confer safety for at least up to one year of administration. Dream vaccine should be inexpensive, easily transferable with minimal cold chain requirements. Nevertheless, majority of the vaccine trials were done on healthy population of age group 18-65 years. The duration of immunity after vaccination is yet to be known. Following SARS-CoV infection, IgG and neutralizing antibody was detectable for 1-3 years following infection indicating vaccineinduced protection may not be long-lasting and re-immunization may be required.[29] It is better to remain alert; maintain physical distancing; early detection and self-isolation, if infected; along with being vaccinated to control the spread of this viral disease. 


\section{REFERENCES}

1. Anon 2020. Coronavirus Resource Center https:// coronavirus.jhu.edu/. [Online] Johns Hopkins University. https://coronavirus.jhu.edu/map.html. [accessed on Nov 26, 2020]

2. WHO. Statement on the second meeting of The International Health Regulation (2005) Emergency Committee regarding the outbreak of novel corona virus (2019-nCoV) 2020. http://www.who.int/news room/ detail/30-01-2020. [accessed on Nov 26, 2020]

3. Wu F, Zhao S, Yu B, Chen YM, Wang W, Song ZG, Hu Y et al. A new coronavirus associated with human respiratory disease in China. Nature 2020; 579 (7798):265-269.

4. Lauer SA, Grantz KH, Bi Q, Jones FK, Zheng Q, Meredith HR, et al. The Incubation Period of Coronavirus Disease 2019 (COVID-19) From Publicly Reported Confirmed Cases: Estimation and Application. Ann Intern Med 2020; 172(9):577-582

5. Centres for Disease Control and Prevention (CDC) How COVID-19 Spreads. CDC 2020. https://www.cdc.gov/ coronavirus/2019-ncov/prevent-getting-sick/how-covidspreads.html? CDC_AA_refVal $=h t t p s \% 3 A \% 2 F$ [accessed on Nov 26, 2020]

6. Shrestha E, Pramanik T, Sur TK. Struggle against coronavirus in Nepal: Present scenario. World J Adv Res Rev 2020; 8(3):125-129.

7. Haynes BF, Corey L, Fernandes P, Gilbert PB, Hotez PJ, Rao S, Santos MR, et al. Prospects for a safe COVID-19 vaccine. Sci Trans Med 2020; 12(568): eabe0948.

8. https://www.gavi.org/vaccineswork?gclid=EAIaIQobCh MIK9CI89PQ8AIVQYNLBROdVQIUEAAYASAAEgLjI $f D \_B w E$ [accessed on Nov 26, 2020]

9. Zimmermann $P$, Curtis $N$. Coronavirus infections in children including COVID-19: an overview of the epidemiology, clinical features, diagnosis, treatment and prevention options in children. Pediatr Infect Dis J 2020; 39(5):355-68.

10. Wrapp D, Wang N, Corbett KS, Goldsmith JA, Hsieh $C L$, Abiona $O$, et al. Cryo-EM structure of the 2019$n C o V$ spike in the prefusion conformation. Science 2020; 367(6483):1260-1263.

11. Buchholz UJ, Bukreyev A, Yang L, Lamirande EW, Murphy BR, Subbarao K, et al. Contributions of the structural proteins of severe acute respiratory syndrome coronavirus to protective immunity. Proc Natl Acad Sci USA 2004; 101: 9804-9.

12. Walls AC, Park YJ, Tortorici MA, Wall A, McGuire AT, Veesler D. Structure, function, and antigenicity of the SARS-CoV-2 spike glycoprotein. Cell 2020; 181(2):281292.

13. Koirala A, Joo YJ, Khatami A, Chiu C, Britton PN. Vaccine for COVID- 19: The current state of play. Paediatr Respir
Rev 2020; 35: 43-49.

14. Rauch S, Jasny E, Schmidt KE, Petsch B. New vaccine technologies to combat outbreak situations. Front Immunol 2018; 9:1963.

15. Clinical trial database of National Institute of Health, US National Library of Medicine, US Department of Health and Human Services. https://www.clinicaltrials.gov [accessed on Nov 26, 2020]

16. Dhama K, Sharun K, Tiwari R, Dadar M, Malik YS, Singh KP, Chaicumpa W. COVID-19, an emerging corona virus infection: advances and prospects in designing and developing vaccines, immunotherapeutics, and therapeutics. Hum Vaccin Immunother 2020 16(6):12321238.

17. Coleman CM, Liu YV, Mu H, Taylor JK, Massare M, Flyer $D C$, et al. Purified coronavirus spike protein nanoparticles induce coronavirus neutralizing antibodies in mice. Vaccine 2014; 30: 32(26) 3169-3174.

18. Thanh Le T, Andreadakis Z, Kumar A, Gómez Román $R$, Tollefsen S, Saville M, et al. The COVID-19 vaccine development landscape. Nat Rev Drug Discov 2020; 19 (5), 305-306.

19. Ou X, Liu Y, Lei X, Li P, Mi D, Ren L, Guo L, et al. Characterization of spike glycoprotein of SARS-CoV-2on virus entry and its immune cross-reactivity with SARSCoV. Nat Commun 2020; 1620, 11.

20. Voysey M, Clemens SAC, Madhi SA, Weckx LY, Folegatti $P M$, Aley PK, Angus B et al. Safety and efficacy of the ChAdOx1 $n$ CoV-19 vaccine (AZD1222) against SARSCoV-2: an interim analysis of four randomised controlled trials in Brazil, South Africa, and the UK. Lancet 2021; 397: 99-111.

21. Zhang C, Maruggi G, Shan H, Li J. Advances in mRNA Vaccines for Infectious Diseases. Front Immunol 2019; 10: 594.

22. Tu YF, Chien CS, Yarmishyn AA, Lin YY, Luo YH, Lin YT, Lai WY et al. A Review of SARS-CoV-2 and the Ongoing Clinical Trials. Int J Mol Sci 2020; 21(7): 2657.

23. Mulligan MJ, Lyke KE, Kitchin N, Absalon J, Gurtman A, LockhartS, et al. Phase 1/2Study to Describe the Safety and Immunogenicity of a COVID-19 RNA Vaccine Candidate (BNT162b1) in Adults 18 to 55 Years of Age: Interim Report; preprint.2020; s.l.:medRxiv,06.30.20142570,2020, medRxiv.

24. Hobernik D and Bros M. DNA Vaccines -- How Far From Clinical Use? Int J Mol Sci 2018;19(11): 3605.

25. Smith TRF, Patel A, Ramos S, Elwood D, Zhu X, Yan $J$, Gary EN et al. Immunogenicity of a DNA vaccine candidate for COVID-19. Nat Commun 2020; 11.

26. Myupchar. Race for COVID-19 vaccine: Covaxin and ZyCoV-D begin human trials in India, Moderna publishes preliminary data from phase 1. https://www.firstpost. com/. [Online] July 15, 2020. [Accessed on Nov 26, 2020] 
27. Coronavirus (COVID-19) Vaccinations. Our World in Data. Sourced from individual healthagencies. https://ourworldindata.org/covid-vaccinations\#sourceinformation-country-by-country [accessed on Nov 26, 2020]

28. Kaur PK, GuptaV. COVID-19 vaccine: a comprehensive status report. Virus Res 2020; 288: 198114.

29. Liu L, Xie J, Sun J, Han Y, Zhang C, Fan H, Liu Z et al. Longitudinal profiles of immunoglobulin $G$ antibodies against severe acute respiratory syndrome coronavirus components and neutralizing activities in recovered patients. Scand J Infect Dis 2011; 43: 515-21. 